\title{
Providential Disorder in
} Plato's Timaeus?

\author{
STEFANO MASO / Università Ca' Foscari Venezia /
}

\section{Order and organization from the Parmenides and the Republic to the Timaeus}

When proposing his explanation of the world and natural reality in the Timaeus, Plato completes what is both an analytical journey and an organization project whose previous landmarks are, in my opinion, the Parmenides and the Republic. ${ }^{1}$

The Parmenides is characterized by the radical requirement of a "search for order". This is what justifies the attempt to solve the aporias of the One and the Many, the Same and the Different, the True and the False, through the illustration and discussion of vari-

1 The present study includes the discussions that followed the presentation of an earlier version at various conferences and seminars, in Milan, Grenobles, Couriciba, Atlanta, and Venice. I thank prof. Sebastian Rand, Georgia State University, for having improved my English. - As for the relationship between the Timaeus and the later dialogues, see Cherniss 1957: 225-266 (repr. in: Allen 1965: 339-378). Cherniss emphasizes the close proximity of these dialogues and, contra Owen 1953: 79-95 (repr. in: Allen 1965: 313-338), confirms the traditional chronology, according to which the Timaeus follows the Republic and the Parmenides. In addition to the Parmenides and the Republic, several other Platonic dialogues (such as the Gorgias, the Phaedrus, and especially the Statesman) are closely linked to the Timaeus. However, the link I am interested here concerns the logical mechanism and the ethical/political dimension. Trabattoni 2009: 168 writes: «Il Timeo presuppone infatti il lavoro svolto nei dialoghi dialettici e, in particolare, la riduzione della dottrina delle idee a modalità espressiva di una più generale dottrina dei principi, in cui l'elemento determinante è il rapporto uno-molti, limite-illimitato ecc.». 
ous aspects of logical and physical complexity, while aiming at an outcome that can be defended on a "logical" level.

Interestingly enough, the procedure employed in the Parmenides can also be found in the Timaeus. For instance, in Prm. 146b-148d, Plato addresses the question of the Same and the Different. Of course, the "different" nature of a given thing (of a given entity) can be observed only by comparing it with a thing (entity) that is other. However, these other things (distinct entities that can be such only by virtue of being "other") share the very feature of being "unlike", which makes them, in this respect, "like" (Prm. 147c). Hence: "the one will be similar and dissimilar to the others; insofar as it is different it will be similar, but insofar as it is similar it will be different". ${ }^{2}$

In other words, precisely because a given entity is the "same" as another (having, like any other entity, its own specific characteristics), it is "different": its specific characteristics (by virtue of being specific) make it different, although the very fact of being Different (i.e. of having, just like any other entity, its own specific characteristics) makes it the Same. Furthermore: "And so, the one, on the one hand, being the same as the others and, on the other hand, since it is different from them, in both cases and in each of them taken individually, would be similar and dissimilar to the others (...). And equally, even with respect to itself, since it has appeared both different from itself and the same to itself, in both cases and in each of them taken individually, will it not be similar and dissimilar?"3

Being the Same and being Different imply a comparison both with what is other than oneself and with oneself. Plato's Parmenides then proceeds to argue that the same goes

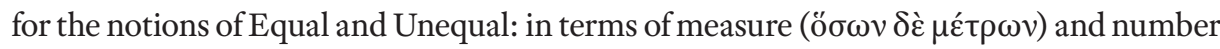
$(\dot{\alpha} \rho \imath \mu \tilde{\omega})$, the One will appear greater, smaller or equal in its constituting parts to itself and to Others (Prm. 149d-151e).

In these examples, as in the ones that follow, Plato is trying to solve the problem of the "relationship" among the entities of the World of Becoming as well as the "relationship" between these entities and the ideas to which they belong. More specifically, he introduces the "participation" mode, i.e., $\mu \varepsilon \dot{\varepsilon} \theta \xi \iota$. $^{4}$ Participating in an idea according to different yet analogous and scientifically comparable modes gives rise to an orderly (at least from a logical-theoretical standpoint) organization of the process of becoming. ${ }^{5}$ As in the Timaeus, the focal point here is the discovery of a principle of order. The different

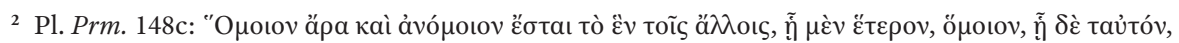

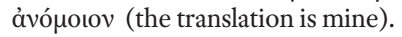

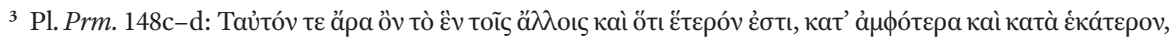

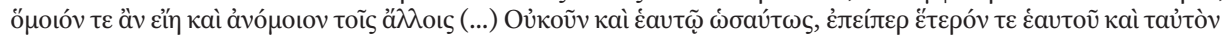

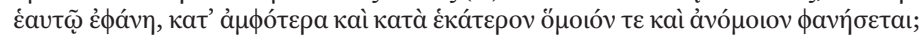

${ }^{4}$ See Pl. Prm. 132d, 158a-b, 163d, and Ti. 58d, 69b. See Brisson 1974: 116-136, and Fronterotta 2001: $195-222$.

${ }^{5}$ In the reality of becoming, which would otherwise be doomed to an infinite division, there emerges a principle of order that brings back the unity among the elements that would otherwise be scattered. Such a principle plays an important role not only in the Parmenides and the Timaeus, but also in the Philebus. See Migliori 2013: 551-555 and 602-609. 
ways in which Plato proceeds in the Parmenides and in the Timaeus must not make us forget the focus which is present in both dialogues. ${ }^{6}$

In the Republic, "logic" is replaced with "justice", for owing to the latter the different components of the civil society contribute in different yet equally essential ways to the establishment of the politeia. Moreover, the analogy between the structure of the State and that of the human soul contributes to consolidating Plato's principle of balance and general order. The different drives and faculties of the psuchê are reflected in the characteristics of different social classes and different forms of government. The idea of the Good is then proposed as the founding principle of the State, of the civic behavior and of the individual virtue. Through Socrates, Plato merely points to this idea as the very source of truth, knowledge, being and essence. ${ }^{7}$ However, this idea perfectly sums up the ethical tension and the metaphysical framework.

My contention is the following: in the Timaeus, the "figure" of the World's Soul (Ti. $34 \mathrm{~b}-37 \mathrm{a})$ re-elaborates in a cosmic perspective what in the Republic is associated with the psuche and the organization of the State. At the same time, this figure revisits, from a naturalistic-generative perspective, the tensions between the Same and the Different, addressed in the Parmenides from an exclusively logical-dialectical one.

The World's Soul is presented as that which permeates the world in every sense; not only is it placed at the centre of the world, but it also envelops it as a circular, revolving sky. The soul is what allows the world to be itself without needing anything else, capable as it is of knowing adequately and appreciating itself. ${ }^{8}$ The World animated by the Soul is truly a happy god: ${ }^{9}$ this is how the divine maker intended it to be.

${ }^{6}$ As for the presence of Parmenides and his thesis in the Timaeus, see Altman 2016: 37-55.

${ }^{7}$ Pl. R. 509a-b: “'It's an incredible beauty you are talking about,' he (scil. Glaucon) said, 'if it is the cause of knowledge and truth, but itself surpasses them in beauty' (...). 'For the things which are known, say not only that their being known comes from the good, but also that they get their existence and their being from it as well'

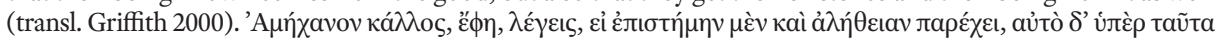

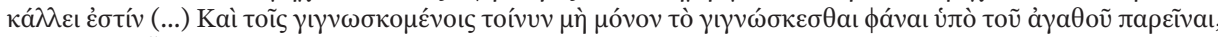

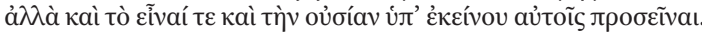

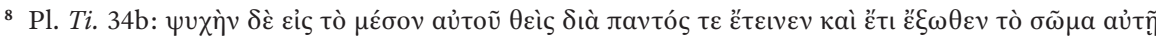

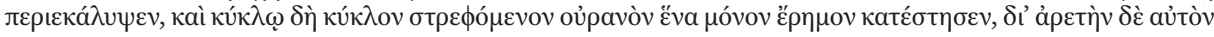

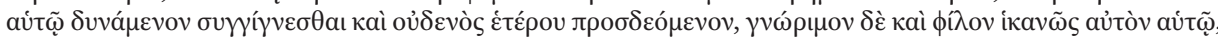
"And in the centre he (scil. the god) set a soul and caused it to extend throughout the whole and further wrapped its body round with soul on the outside; and so he established one world alone, round and revolving in a circle, solitary but able by reason of its excellence to bear itself company, needing no other acquaintance or friend but sufficient to itself". I am quoting from Cornford's translation of the Timaeus. The recent Waterfield translation, 2008 , is - generally - very good, but I find it unsatisfactory to use "creation" instead of "generation" [Greek:

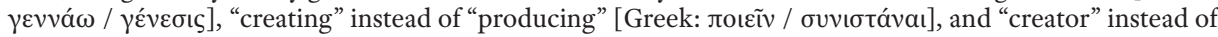

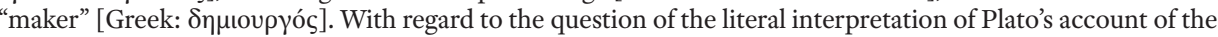
origin of the cosmos, see in particular Tarán 1971: 372-407 and Altman 2016: 55-90, who, reasonably, rules such an interpretation out.

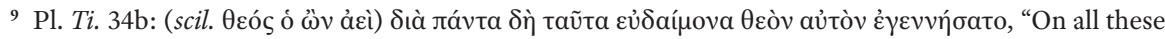
accounts the world which he brought into being was a blessed world". 
It is worth noting that through the construction of the World and the World's Soul Plato means to solve the dialectics between divisibility and indivisibility, between the Same and the Different. ${ }^{10}$ In practical terms, within the "idea-becoming" model the relationship and the sense of the relationship between the One and the Many come into play. Each entity (which exists by virtue of being an entity) is self-identical and different from what is other than itself, although it is modeled on the image of the idea to which it refers. In this sense, the divine maker merges the indivisible being (which is always self-identical) with the divisible one (which undergoes a process of becoming in the different bodies), thereby, originating a third kind of being. The very natures of the Same and the Different play a crucial role in such a composition, which remains between the indivisible and the divisible, and which is generated within the bodies. This complex operation meets the resistance of the nature of the Different until it is "forcibly harmonized", tìv

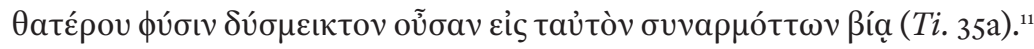

Plato's entire passage is quoted below:

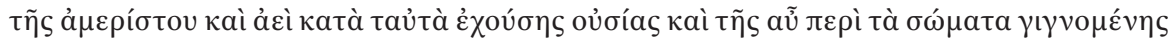

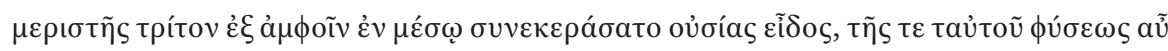

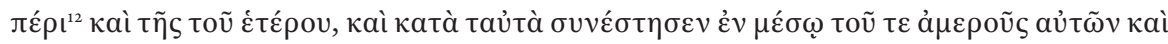

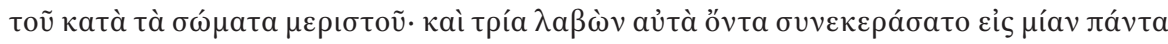

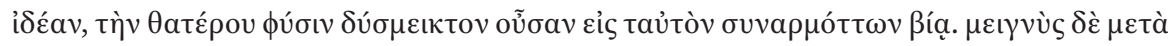

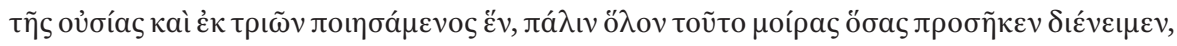

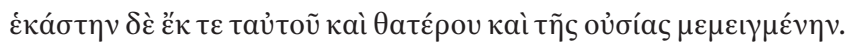

From the indivisible Substance that is ever in the same state and from the divisible Substance that becomes in bodies, he pulled out a third form of Substance composed of both. Again, from the nature of Sameness and that of Difference, he also on the same principle made a compound intermediate between the kind of them that is indivisible and the kind that is divisible in bodies. Then, taking the three, he blended them all into one ideal reality, forcibly harmonizing the nature of Difference, hard as it was to mingle, with that of Sameness. And having mixed them together with Substance, and made a unity of the three, he again divided this whole into as many parts as was fitting, each part being a blend of Sameness, Difference, and Substance (Ti. 35a-b, transl. Cornford modified).

10 On this see Brisson 1994: 517-527; Lisi 1997: 251-259; Zedda 2000: 23-28.

${ }^{11}$ For the first accurate interpretation of the construction and structure of the World's Soul in Plato, see Taylor 1928: 105-136; Cornford 1966: 57-66; and in particular Moreau 1981: 30-55. Important are also Brisson 1994: 270-314 and Mohr 1985: 18-27, 171-177. More recently, Parry 1991: 13-32, in his analysis on the intelligible world-animal in Plato's Timaeus, has shown that "completeness" and "complexity" explain why the "intelligible living being" serves as a paradigm of the construction of the cosmos. For the epistemological implication thereof, see Gregory 2000: 242-255.

12 This second aũ $\pi \varepsilon ́ p เ$ is removed by Burnet 1902 and Rivaud 1925, who follow Sextus Empiricus and Cicero. It is reintroduced in the critical edition of Serrano Cantarín - Díaz De Cerio Díez 2012: 83-85. 
The passage focuses on the "harmonization" of that which exists, that is of the substance (oúoía) determined as an entity or a series of entities. It is worth noting that the possibility for Sameness and Difference to be kept together (i.e. "harmonized") is, on the one hand, the result of what has already been harmonized and, on the other, the cause of future harmonizations: in each of the latter, Sameness and Difference are merged in such a way as to turn them into something that exists.

Whether the cosmos presented in the Timaeus does or does not have a predominantly metaphorical value, it is evident that this structure hints at a kind of historical-evolutionary development. Moreover, it clearly receives nothing from outside, as it already contains all that will be manifested in the form of becoming.

\section{... from disorder to order to disorder to ...}

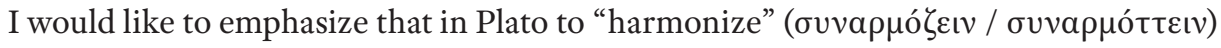
means "to arrange in an orderly manner" that is "logical and suited to the circumstances". As for harmony, it evokes the notions of Balance and Equality, and, therefore, of Uniformity: ó $\mu a \lambda i \zeta \xi ı v / ~ o ́ \mu a \lambda i ́ v \varepsilon ı v$ ("to make equal, uniform”). Now, when the complex process, based in both contexts on the figure of the circle $(\rightarrow \text { disorder } \rightarrow \text { order } \rightarrow \text { disorder } \rightarrow)^{13}$ has been recognized in the structure of the cosmos and that of human beings it is time to see how it can be used to illustrate both the ontological necessity of becoming and the providential strategy that defines the actions of the demiurge. ${ }^{14}$

Plato explicitly introduces the figure of the circle shortly after the above-cited passage (Ti. 36b ff.) to explain how the parts that are cut off from the "whole" (Ti. 35b) are combined: by bending and uniting, at the point that is opposite to their intersection, the respective extremities of the parts that compose a kind of letter $\chi$, two concentric circles are obtained. Once the two circles were set in motion, the demiurge "named

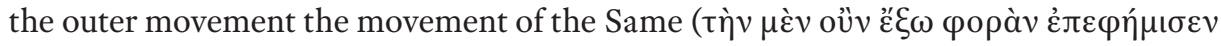

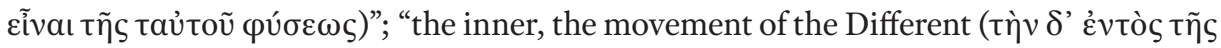

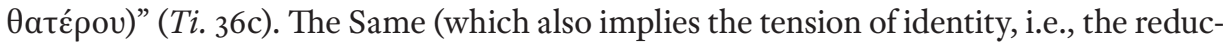
tion of similarity to identity) ${ }^{15}$ holds supremacy (крátos) and is single ( $\mu$ íav) as well as undivided (ä $\chi\llcorner\sigma \tau o v)$. In other words, in its completeness and organization, it includes

13 See Maso 2003: 243-257. The tight implication between the harmonization of the soul and that of the physical-corporeal part of the world is clearly documented: "When the whole fabric of the soul had been finished

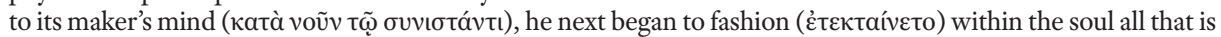

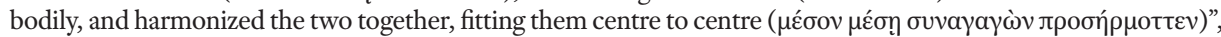
Pl. Ti. 36d-e.

${ }^{14}$ Ferrari 2003: 91-94, claims that a "rational and teleologically oriented" causal tension coexists, within the demiurge, with a "necessary" causality that derives from the paradigmatic nature of the ideal model. On the meaning and role of the paradigm in the cosmic and cosmic-metaphysical dimension, see Broadie 2012: 63-74.

15 Regarding the demiurge, Plato points out: "And he gave the supremacy to the revolution of the Same and

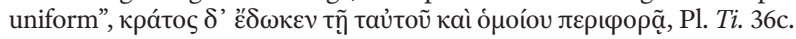


"everything". The Different, of course, can only become diversified and produce a series of circles: seven circles, unequal, but moving according to harmoniously determined circumferences, speeds and senses of rotation. ${ }^{16}$

The Different holds no supremacy. Let us here stress, however, that along with identity, diversity comes necessarily back into play to explain the structure of the One, which is self-identical while also constituting the paradigm that configures the difference it contains. Without the presence of the Different, the universe could not be built; the World's Soul could not express itself, envelop the physical multiplicity of the universe, and endow it with a unified and harmonious meaning. ${ }^{17}$ This is why the World's Soul

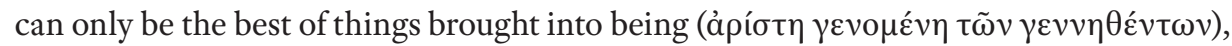

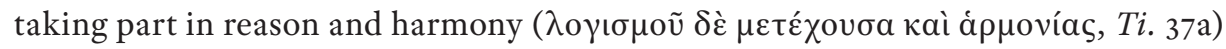
because the principle of its partition is rational proportionality.

With reference to human beings and their physical structure, Plato emphasizes the consequences of the World's Soul's highest characteristics; the individual soul is the divine part which allows human body to stand erect and which, in its search for truth, thinks immortal and divine thoughts precisely because it partakes in immortality (Ti. 9oc-d). To act in accordance with this part makes us happy and immortal. Plato adds:

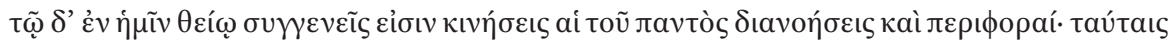

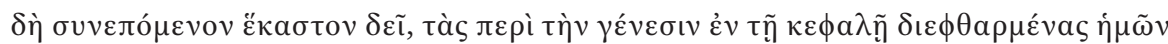

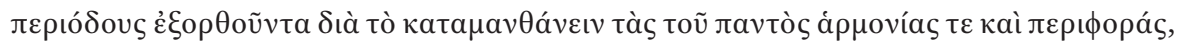

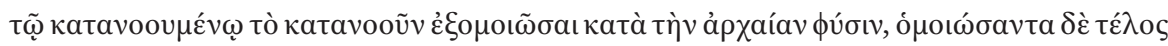

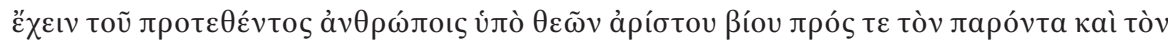

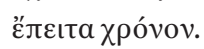

The motions akin to the divine part in us are the thoughts and revolutions of the universe; these, therefore, every man should follow and, correcting those circuits in the head that were deranged at birth by learning to know the harmonies and revolutions of the world, he should bring the intelligent part, according to its pristine nature, into the likeness of that which intelligence discerns, and, thereby, win the fulfillment of the best life set by the gods before mankind both for this present time and for the time to come.

This quotation comes from the final part of the Platonic dialogue. From the ethical perspective advocated there, human individuals are all encouraged to refine and

${ }^{16}$ Plato aims here to describe the astronomical organization of the cosmos. On this passage, see in particular the reconstruction and representation of the armillary sphere by Brisson 1994: 38-44. The harmony that charac-

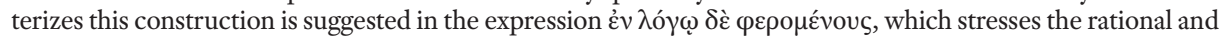
rhythmic motion of the seven planetary circles.

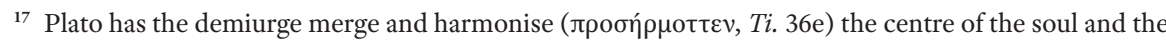
centre of the body; from that point on, the soul can expand in any direction and, thus, envelop the entire sky from outside: "̌́ $\xi \omega \theta \varepsilon v \pi \varepsilon \rho \iota \kappa a \lambda u ́ \psi \alpha \sigma a, i b i d$. Such a rotation is endless and rationally determined, which is the divine

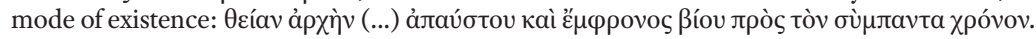


improve themselves in the name of "the harmonies and revolutions of the universe (tàs

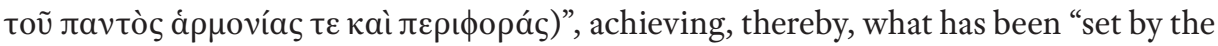
gods". This divine (and, therefore, providential) pre-determination of what humans must do to be happy was already explained when Plato described the functioning of the

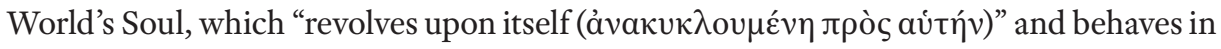
the following manner:

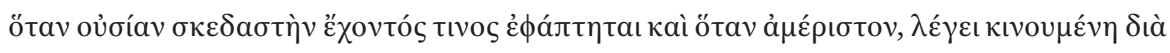

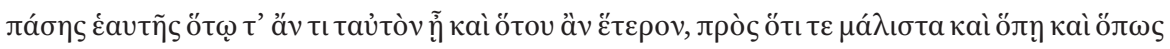

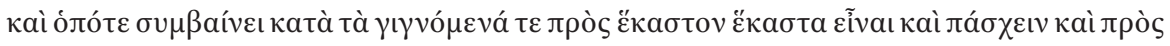
tà Katà tav̉ià ézovta ảé́.

When it is in contact with anything that has dispersed existence or with anything whose existence is indivisible, because it is set in motion all through itself, it tells what thing something is identical with and from what is different, in what respect precisely, and how, and in what sense, and when: and it tells what individuals are related to, and what they are affected by, both in the world of generation and in the world of immutable beings. (Ti. 37a-b, transl. Cornford modified).

In other words, the World's Soul outlines the evolution of the becoming of the Many and of the humans acting therein, according to a logic which, while inducing harmony, highlights again the centrality of the binomial Same / Different with respect to harmony.

Summing up: 1) the structure of the universe in the Timaeus is all-embracing, 2) its logic relies on the dynamic relationship between identity and diversity, 3) it achieves, thereby, a kind of harmony in which everything makes sense and is well-balanced, 4) the World's Soul is the all-determining factor and 5) individual human beings that long for truth and justice should adapt to this.

\section{Deterministic tension in Plato's views?}

One should recognize that in this perspective there arises the same deterministic tension that was subsequently characteristic of the Stoics, who carried it to its extreme consequences. ${ }^{18}$ However, the expression of the deterministic tension and, thereby, the effec-

\footnotetext{
18 See Moreau 1981: 173-186. Reydams-Schils 1999, studied the influence of the Timaeus on the Stoic and Middle Platonic traditions. As she correctly points out, "There remains the most hypothetical point that the Early Stoics might have read the Timaeus as a cosmic republic, a counterpart to Plato's work on the ideal state" (Reydams-Schils 1999: 246). In any case, Plato's explanation of the role of nature, providence, necessity and fate in the Timaeus clearly also underlies the concept of the Stoic $\lambda$ ó $\gamma$ os and of the cyclical life of the cosmos: (Reydams-Schils 1999: 70-79).
} 
tive - and historical - actualization of everything depend on two factors: the "disorder" of the Many, and the principle of "harmony" that can be opposed to it.

Regarding the state of Disorder, which is the premise to the constitution of Order, there seems to be no misunderstanding: 30 a describes the passage from Disorder to

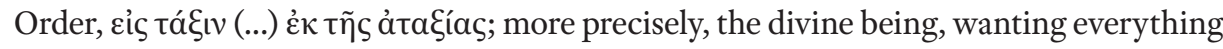
to be good and as perfect as possible, intervenes and brings back to order anything that is

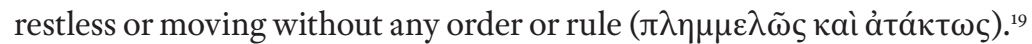

As for harmony, it immediately refers to the original state of Order expressed in the rotation of the circles that constitute the universe and, in particular, of the circles of the Same and the Different $(T i .36 \mathrm{c}-\mathrm{d}$ e $37 \mathrm{~b}-\mathrm{c})$. But this is the same harmony that governs the sentient activities of humans and the movements of their souls:

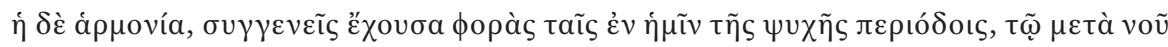

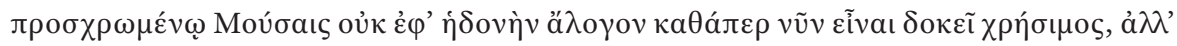

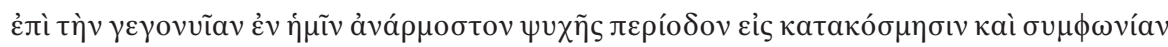

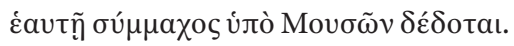

And harmony, whose motions are akin to the revolutions of the soul within us, has been given by the Muses to him whose commerce with them is guided by intelligence, not for the sake of irrational pleasure (which is now thought to be its utility), but as an ally against the inward discord that has come into the revolution of the soul, to bring it into order and consonance with itself (Ti. 47d).

Disorder as a necessary condition. The presence of pronoia.

A "state of disorder" and an available "ideal principle of harmony" constitute, therefore, the conditions for the perfection of everything that is orderly. ${ }^{20}$ Of course, human intelligence plays a crucial role in this harmonious transition from disorder to order; ${ }^{21}$ the same intelligence is already present in the World's Soul and serves as a paradigm for humans, though it is mostly expressed as "necessity". Crucially, Plato points out that "The generation of this universe was a mixed result of the combination of Necessity and Reason", oũv

\footnotetext{
19 As to the pre-cosmic motion, see Vlastos 1939: 71-83; and Skemp 1985: 289-299. This two scholars agree in pointing out that the chaotic motions remain the necessary factor in explaining the phenomena of the universe. An effective presentation of the various scholars' interpretations of the pre-cosmic, erratic movement is to be found in Mohr 1985: 116-119. This scholar, for his part, thinks that the motions of the Timaeus' pre-cosmos are purely mechanical in origin: only in the Phaedrus and in the Laws X do the erratic movements have psychic causes.

${ }^{20}$ Neither condition should be overlooked to fully comprehend the "proto-historical structure" that characterizes the formation of the cosmos and that underlies the structure of the Timaeus. On this last point, see Broadie 2012: 256-264.

${ }^{21}$ The transition implies motion: a disorderly motion that tends to be ordered in view of the final result. Vlastos 1965: 80-83, emphasizes that this movement is “one of the soul's ingredients".
} 


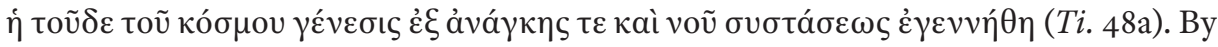
necessity we mean that which results not from a more or less sentient decision but from a succession of events that may originally be random but inevitably lead to a predictable and, thus, mechanically determined event. ${ }^{22}$ Plato identifies, therefore, the explanatory key of the universe with a logic of necessity that is ultimately combined with reason once the disordered causality has been controlled. ${ }^{23}$

Consequently, the demiurge should be seen not only as the organizer of the World of Becoming according to the model constituted and activated by the World's Soul, but also as the interpreter of the necessity sustaining the existence of the universe. In Plato's words:

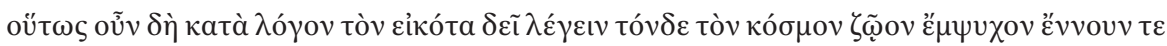

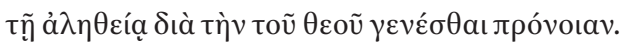

This, then, is how we must say, according to the likely account, that this world came to be, by the god's providence, in truth a living creature with soul and reason ( Ti. $3 \mathrm{ob}-\mathrm{c}$ ).

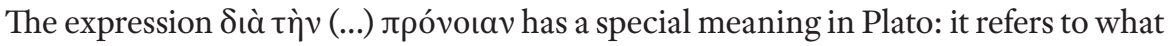
awaits us in future. However, in view of this future we previously performed a particular action or chose to behave in a certain way. This future does not refer to something that is probable but to something that meets all the requirements for becoming true. In the Timaeus, $\pi \rho$ óvoเa is attributed to the divinity on two occasions: in the passage quoted above $(T i .3 \mathrm{Ob}-\mathrm{c})$ and in $44 \mathrm{c}$, which addresses the question of whether it is necessary to analyse the "foresight" of gods, i.e., the design behind their decisions ${ }^{24}$. In addition to this, in the language of myth, the auriga (Phdr. 254e) holding the reins also has his own project: "the bad horse calms down and now that it has been humbled it lets itself be guided

\footnotetext{
22 On the concept of necessity in relation to Plato's intelligence, see Cornford 1966: 162-177. Cornford argues that such a "necessity" ultimately relies on random causality: the latter is an errant cause ( $\pi \lambda \alpha \nu \omega \mu \varepsilon ́ v \eta$ aitía, 48a), something that we could call an irrational element intrinsic to the World's Soul. More critically, Charles (2006: 48-57) explains ảvá $\gamma \kappa \eta$ as the "disordering cause"; this scholar takes ává $\gamma \kappa \eta$ as a real force, but, contrary to Cornford, she points out that "at no place in the Timaeus is ává $\gamma \kappa \eta$ ever described as being a force within nature. Rather, it is specifically rendered as a force, along with voũ , which preceded the generation of the physical Cosmos" (Charles 2006: 78).

23 Tellingly, Plato writes that "this universe was fashioned in the beginning by the victory of reasonable

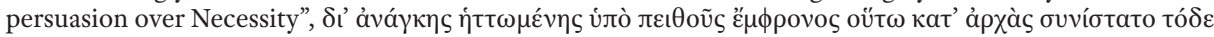

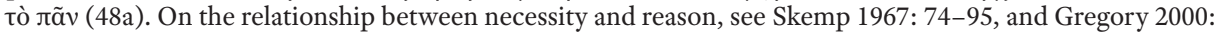
113-115. On the necessary role played by causality independently of any intelligence, see Johansen 2003: 70-72. Charles 2006: 38-42, discusses the meaning of causality in the Timaeus and stresses the centrality of its ontological value (e.g. Ti. 18e), its logical-deductive value (Ti. 28a-48a) and the value of the idea of process (e.g. Ti. 57c).

${ }^{24}$ In the section of the Timaeus devoted to the generation of gods and men, souls and bodies, Plato carefully examines the development of living beings, and asserts: "Our present subject must be treated in more detail; and its preliminaries, concerning the generation of bodies, part by part, and concerning soul, and the reasons and

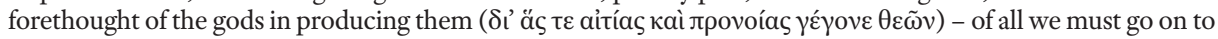
tell, on the principle of holding fast to the most likely account."
} 


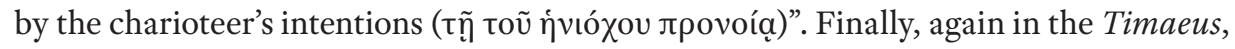
Plato claims that human face gathers the instruments (ö $\rho \gamma \alpha v a$ ) that are necessary for the

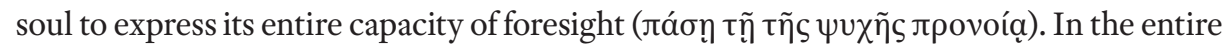
corpus Platonicum, providence, understood as a way of deliberately planning the future, is mentioned only four times. ${ }^{25}$ Significantly, it is presented as the defining feature of the role of the god and, hence, of the process of being governed by the god. ${ }^{26}$

At this point we can infer that in the Timaeus harmonization, i.e., the reduction of the meaningless to the meaningful whose existence is good as such, occurs according to a logic that is connected with the nature of necessity and that accompanies the way in which the god foresees the occurrence of becoming. ${ }^{27}$ Without the contribution of the god, this orderly and meaningful organization of matter could occur only in a random and circumscribed way:

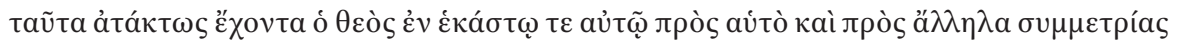

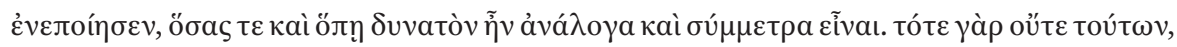

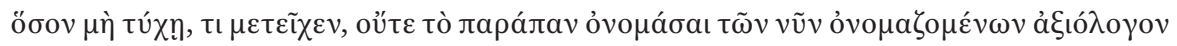

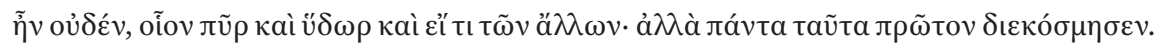

These things were in disorder and the god introduced into them all every kind of measure in every respect in which it was possible for each one to be in harmonious proportion both with itself and with all the rest. For at first they were without any such proportion, save by mere chance, nor was there anything deserving to be called by the names we now use - fire, water, and the rest; but all these he first set in order (Ti. 69b).

${ }^{25}$ In addition to these four mentions (three in the Timaeus, one in the Phaedrus), we also find the adverbial

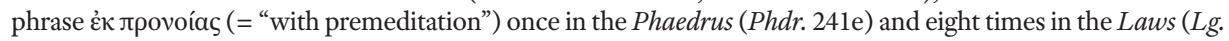
721c; 838c; 871a; 873a; 874e; 877b; 877c; 932e). That is all.

${ }^{26}$ In Laws 903b-c the role of the demiurge is evoked in the context of the ideal organisation of the cosmos,

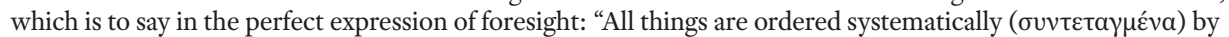

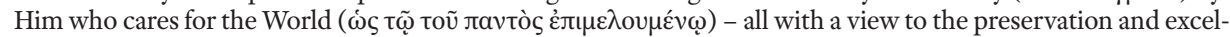
lence of the Whole, whereof also each part, so far as it can, does and suffers what is proper to it. To each of these

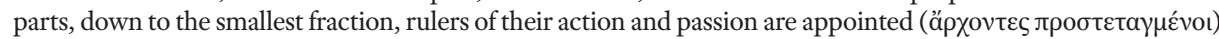
to bring about fulfillment even to the uttermost fraction; whereof thy portion also, O perverse man, is one, and

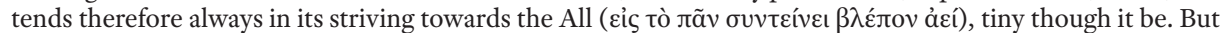
thou failest to perceive that all partial generation is for the sake of the Whole, in order that for the life of the World-all blissful existence may be secured, - it not being generated for thy sake, but thou for its sake. For every

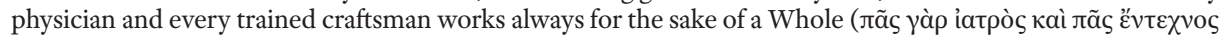

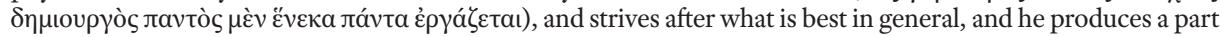

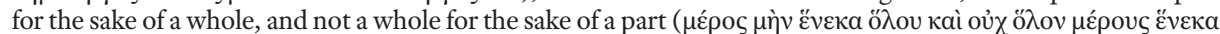

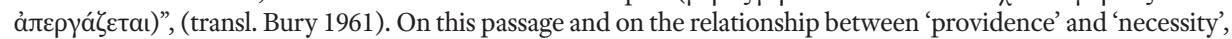
see Reydams-Schils 1999: 73-79.

${ }^{27}$ When discussing the geometrical structure of the original elements and the ensuing stereometry, Plato points to the direct role of the god at the moment of organizing the universe, combined with the original necessity of the elements themselves: "And with regard to their numbers, their motions, and their powers in general,

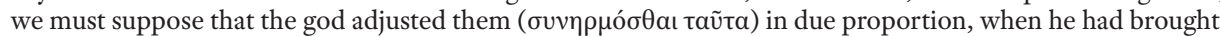
them in every detail to the most exact perfection permitted by Necessity willingly complying with persuasion

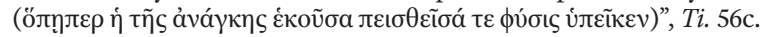


It is noteworthy that randomness is not excluded from Plato's process of organiza-

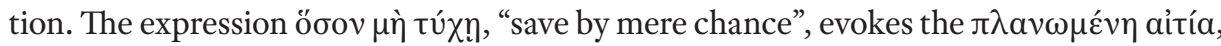
"Errant Cause" ${ }^{28}$ which, combined with what the intellect can produce, gives rise to the process of becoming.

What is perhaps even more remarkable is that the starting point should be constituted

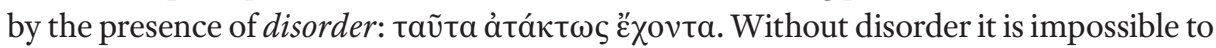
conceive not only of the possibility of order but also of history understood as the gradual configuration of the world constituted by regular symmetries and proportions.

At this point, one needs to mention the well-known myth of the history of the cosmos in Plato's Statesman (Plt. 269c-274e). ${ }^{29}$ The stranger from Elea explains to Socrates the Younger that the god himself guides and accompanies the circular movement of the cosmos, thus, bringing it gradually closer to the state of perfect equilibrium. But at this point the god retreats and leaves the cosmos free to move on its own. Then, the rotation changes direction, as the physical nature of the cosmos cannot be the same as the divine one. An entropic situation ensues: the rate of disorder and destruction increases and intensifies until the god returns to attend to the universe and all its parts, bringing it close to order again. The process is reminiscent of a ship's pilot returning to the tiller after a short absence, and gradually steering the ship back on the right track.

During a certain period God himself goes with the universe as guide in its revolving course, but at another epoch, when the cycles have at length reached the measure of his allotted time

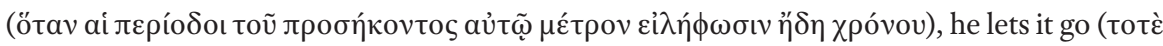
$\delta \grave{\varepsilon} a \dot{v} \tilde{\eta} \kappa \varepsilon v$ ), and of its own accord it turns backward in the opposite direction, since it is a living

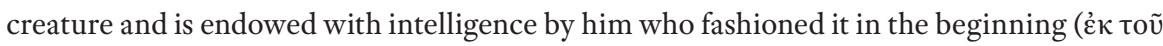

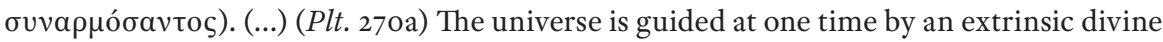
cause (...) at another time it is left to itself and then moves by its own motion, being left to

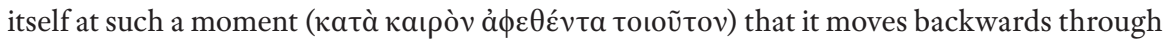

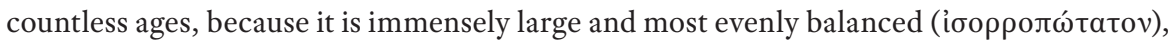
and turns upon the smallest pivot. (...) (Plt. 272d-e) For when the time of all those conditions was accomplished and the change was to take place ... then the helmsman of the universe

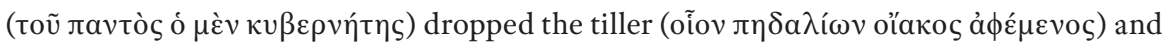

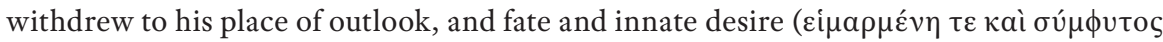
غ̇лı $\theta u \mu i ́ a)$ made the earth turn backwards. (...) (Plt. 273a) And as the universe was turned back and there came the shock of collision, as the beginning and the end rushed in opposite

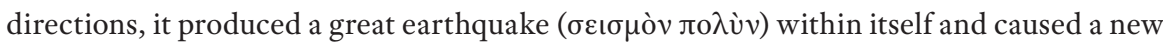
destruction of all sorts of living creatures. (...) (Plt. 273d-e) Therefore, at that moment God,

${ }^{28}$ See Tim. 48A. On the necessary character of the Errant Cause, see Cornford 1966: 159-160. In particular, Taylor 1928: 303-304, underlines its role after the first four elements have been "selected". Now, see Mohr 1985: 119-136.

29 See Mohr 1985: 141-157. The various exegeses of the myth are now discussed in Dixsaut 2018: 333-382. 


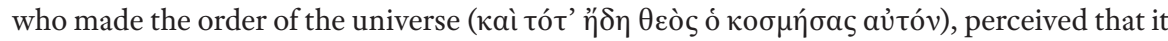
was in dire trouble, and fearing that it might founder in the tempest of confusion and sink in

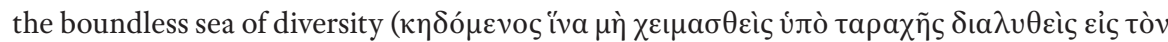

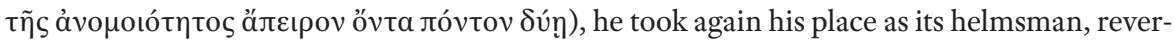
sed whatever had become unsound and unsettled in the previous period when the world was

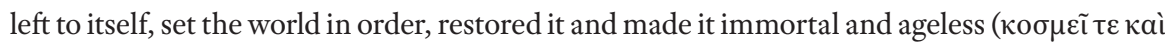

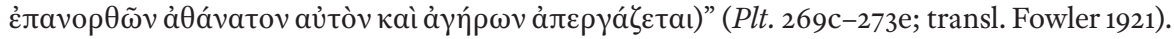

While expressed in a political key through the figure of the State regent - in perfect accordance with the perspective of the Republic $-{ }^{30}$ the myth that is proposed here clearly complies with the ontological-cosmological framework of the Timaeus. ${ }^{31}$ The pilot-regent

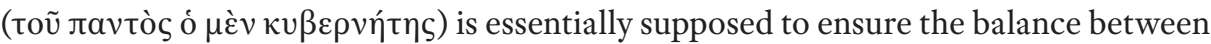

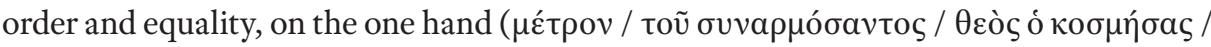

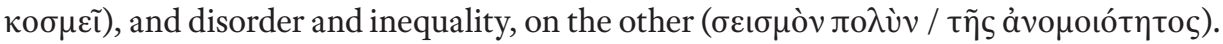

A vital role is played by the combined yet distinct impact of the intelligence of the regent and that of the universe, which is alive. The former knows how to seize the right

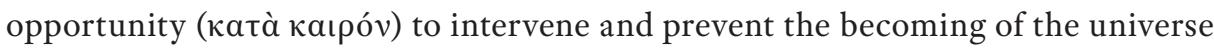
from being repressed by equality and identity in the name of a project of absolute order ensured by the correct steering of the tiller ( $\pi \eta \delta a ́ \lambda เ o v)$. The latter knows how to move

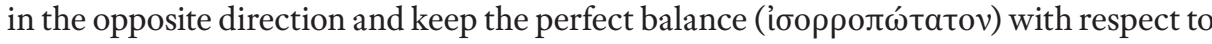
the circle of becoming, abiding, thereby, by its own destiny and innate directional drive

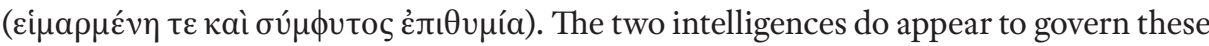
two opposing drives. However, it is the pilot who decides when it is the right time to take up the tiller and correct (غ่лavo $\rho \tilde{\omega} v$ ) the course of the ship for another stretch of sea.

In other words, cosmic cycles are eternally articulated around the tension of order and disorder, neither of which can prevail over the other, lest the balance be lost, leading to a dissolution through destruction or to a standstill in the process of becoming due to a loss of differentiation between the entities that constitute the whole. Nevertheless, there can be no doubt about the god's strategy and capacity of foresight (i.e., of having

30 As is well known, the role of State regent is to ensure the best possible functioning of the polis, i.e., to ensure order. Voegelin 1990: 170-214, emphasizes that the managing order and disorder is part of Plato's wider ethical and political project. However, this means that "The order of the cosmos has become consubstantial with the order of the polis and of man" (Voeglin 1990: 184).

31 Brisson 1994: 189-205, studies the distinct components of the cosmos and the movement that keeps them together, and highlights how the cosmological model found in the Timaeus has a mathematical nature but an ethical-teleological intent. On the crucial relationship between stillness and motion, see Pl. Ti. 57e-58a, where

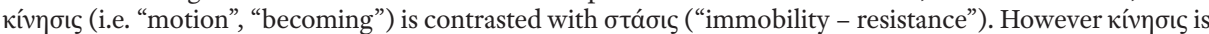

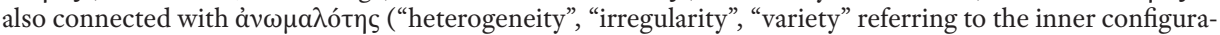
tion of cosmic bodies) and with ávıoótn ("inequality" in the relationship among the various bodies). As for

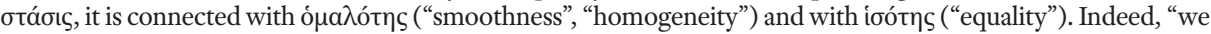
must always presume rest in a state of homogeneity, and attribute motion to a condition that is heterogeneous.

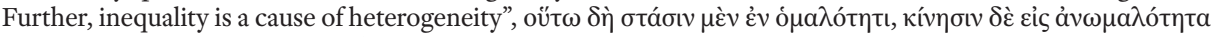

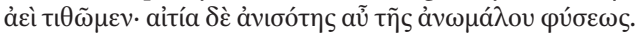


a clear design for the future and acting accordingly). The aim is to avoid drowning in the

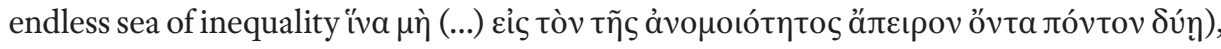
while simultaneously allowing some space for inequality, and leaving the universe free $(\dot{\alpha} \vee \tilde{\eta} \kappa \varepsilon v)$ to periodically give in to the movement which is intrinsic to its innate tension.

Finally, let us note that the necessity of balancing the forces is associated with periodicity and, therefore, with circularity in perfect accordance with the constitutive metaphysical structure proposed in the Timaeus, in which voũ s and ává $\gamma \kappa \eta$ (understood as a non-orderly causal force) generate the cosmos.

\section{Harmonious balance of the cosmos as fruit of providential contribution of both order and disorder}

To conclude, I have raised the problem of the difference between two modalities of presence (or activity) of providence: that which conforms to the order and that which pertains to the disorder. Now, the following question arises: how does these two presences (or activities) relate to each other? Is the harmonious balance of the cosmos a fruit of some occasional structure in which two opposite yet equally necessary forces - characterized by two modalities of providence - work?

And if - as Plato knows - in an urban setting any serious $\delta \eta \mu \iota 0 \rho \gamma o ́$ s is capable of moving in the direction of harmonious balance, and step by step proceeds toward the order, ${ }^{32}$ then - in a cosmic perspective - the life of the Whole is due to the providential possibility of rationally overcoming and enhancing (but never eliminating) the conflicts between the separate parts and the opposing tensions. Disorder is the necessary addition (or counterpart) to the experience of the intelligent providential craftsmanship. This is the paradoxical "providential" presence of disorder: because of its "providential" pre-cosmic and intermittent cosmic activity, the demiurge can manifest his "providential" action.

\section{From Plato to Neoplatonism. The providential disorder.}

Finally, I just would like to point out that Plotinus was aware of this fact: ${ }^{33}$ i.e., of the role of the conflicting elements, which, according to Plato, were constituted by the necessary disorder (ảvá $\gamma \kappa \eta)$ and by the order imposed by the demiurge (voũ $)$. As we know, Plotinus went beyond the limitations of both Platonic and Stoic conceptions:

32 Pl. Grg. 503e: "You have (...) to see how each of them (scil. $\delta \eta \mu$ toupүó $)$ arranges everything according to

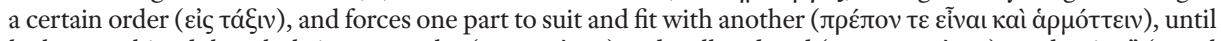

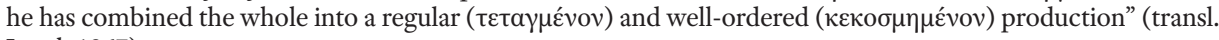
Lamb 1967).

33 See Chiaradonna 2014: 187-210; esp. 203-207 on the "providence without craftsmanship." 
For though it is at war with itself in its parts, it is one thing and on good terms with itself ( $\varepsilon^{\prime} v$

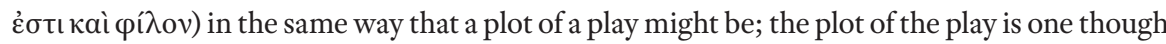
it contains in itself many battles. Of course, the play brings the conflicting elements into a kind

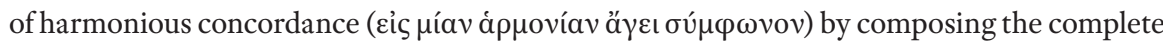
story of the persons in conflict; but in the universe the battle of conflicting elements springs

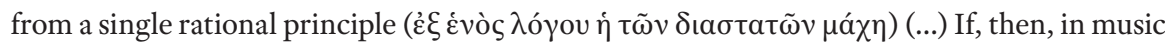
the laws of rational proportion make high and low notes and come together into a unity (Eis

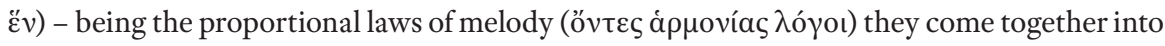

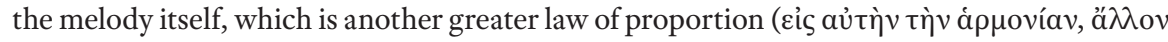
$\lambda$ ó $o v \mu \varepsilon i$ (ova), while they are lesser ones and part of it; in the universe, too, we see the opposites, for instance, white-black (...) but all are parts of the single universal living being, and the

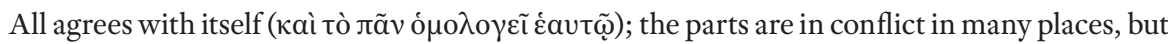

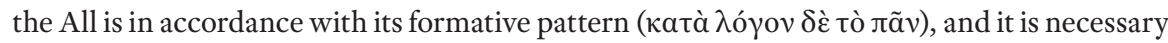
that this one formative pattern should be one pattern made out of opposites (ảvá $\gamma \kappa \eta$ кaì tòv

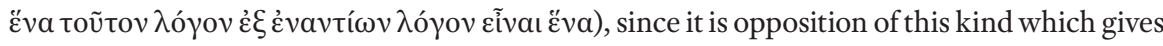
it its structure, and, we might say, its existence. (Plot. 3.2.16.34-50, transl. Armstrong 1967).

Of course, we must keep in mind the traditional interpretation of the first principles, on which the generation of the cosmos depends according to Plotinus and Neoplatonism, i.e., the thesis that there are two discrete processes of becoming: one involving the soul in the production of what is good, and the other (matter) which is the source of disturbance and what is worse. Remarkably, the production of that which is worse is identified with the ává $\gamma \kappa \eta$ of the Timaeus and it depends on the "ancient nature" of the pre-cosmic disorder. ${ }^{34}$ In this way, the demiurge becomes the divine creator and the donor of order, while the evil originates from this 'ancient nature' that endures in the generated cosmos and continues to produce disorder. ${ }^{35}$

What I wish to emphasize - and scholars generally disregard this point - is Plato's attempt to combine the two principles or processes: the real life of the cosmos is precisely the consequence of this mediation (Plotinus likewise suggests this when he theorizes about the harmony of the conflicting elements). This "mediation" aims at order in the sense that it is destined to become order but has disorder as its necessary condition. That is why I think we should label this disorder as "providential".

${ }^{34}$ See, e.g., Procl., de mal. subsist. 34 (transl. Moerbeke): Hoc igitur est qui anterius habitus: non enim potens obtineri speciebus inornatum se ipsum ostendit et inpulcrum (...) causam inordinationis universi in subiectam naturam remittit (scil. Plato), a componente quidam bona habere mundum dicens, ab eo autem qui anterius habitu

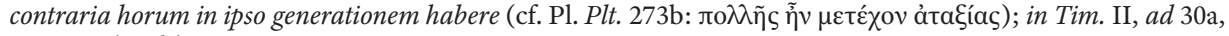
382-383 (Diels).

35 See Phillips 2007: 117-125. 


\section{BIBLIOGRAPHY}

Allen, R., 1965, Studies in Plato's Metaphysics, London.

Altman, W. H. F., 2016, The Guardians in Action. Plato the Teacher and the Post-Republic Dialogues from Timaeus to Theaetetus, Lanham - Boulder - New York - London.

Anton, J., Kustas, G. (eds.), 1971, Essays in Ancient Greek Philosophy, Albany.

BRIsson, L.,1994², Le même et l'autre dans la structure ontologique du 'Timée' de Platon, Sankt Augustin (the first edition: Paris 1974).

BroAdie, S., 2012, Nature and Divinity in Plato's Timaeus, Cambridge.

Burnet, I. (rec.), 1902, Platonis opera, vol. IV, Oxford.

Calvo, T., Brisson, L. (eds.), 1997, Interpreting the Timaeus-Critias: Proceedings of the IV Symposium Platonicum: Selected Papers, Sankt Augustin.

Charles, S. R., 2006, The Emergent Metaphysics in Plato's Theory of Disorder, Lanham -Boulder - New York - Toronto - Oxford.

Cherniss, H., (1957), “The Relation of the Timaeus to Plato's Later Dialogues”, American Journal of Philology 78, pp. 225-266 (the first edition: Allen 1965, pp. 339-378)

Chiaradonna, R., (2014), "Plotinus' Metaphorical Reading of the Timaeus: Soul, Mathematics, Providence", in: D’Hoine - Van Riel 2014, pp. 187-210.

Cornford, F. M., (1966), Plato's Cosmology: the Timaeus of Plato. Translated with a running commentary, London (the first edition: 1937).

D’HoIne, P., VAn Riel, G. (eds.), 2014, Fate, Providence and Moral Responsibility in Ancient, Medieval and Early Modern Thought. Studies in Honour of Carlos Steel, Leuven.

Dixsaut, M., 2018, Platon. Le Politique, Intod., trad., et commentaire par M. Dixsaut et A.A., Paris.

Ferrari, F., 2003, “Causa paradigmatica e causa efficiente: il ruolo delle idee nel Timeo”, in: Natali - Maso 2003, pp. 83-94.

Ferrari, G. R. F. (ed.), 2000, in: Plato. The Republic., G. R. F. Ferrari (ed.), T. Griffith (transl.), Cambridge.

Frede, M., 1988, "Being and Becoming in Plato", Oxford Studies in Ancient Philosophy (suppl. vol.), pp. $37-52$.

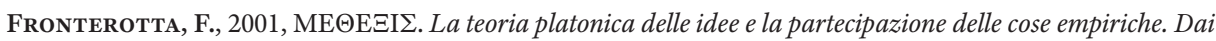
dialoghi giovanili al 'Parmenide', Pisa.

Gotthelf, A. (ed.), 1985, Aristotle on Nature and Living Things: Philosophical and Historical Studies presented to D. M. Balme on his Seventieth Birthday, Pittsburgh - Bristol.

Gregory, A., 2000, Plato's Philosophy of Science, London.

Gregory, A., 2008, Introduction, in: Plato, 'Timaeus' and 'Critias', R. Waterfield (transl.), Oxford, pp. iv-xliv.

Johansen, T. K., 2003, “The Place of the Demiurge in Plato's Teleology”, in: Natali - Maso 2003, pp. 65-82.

Lisı, F., 1997, "La construcción del alma del mundo en el Timeo (35a-b) y la tradición indirecta”, in: Calvo Brisson 1997, pp. 251-259.

MAso, S., 2003, “Dal disordine all'ordine”, in: Natali - Maso 2003, pp. 243-257.

Migliori, M., 2013, Il disordine ordinato: la filosofia dialettica di Platone, Brescia.

Mohr, R. D., 1985, The Platonic Cosmology, Leiden.

MoreaU, J., 1981, L’Âme du monde de Platon aux Stö̈ciens, Hildesheim - New York (the first edition: Paris: 1939).

Natal, C., Maso, S. (eds.), 2003, Plato Physicus. Cosmologia e antropologia nel 'Timeo', Amsterdam (ripr. Venezia 2011). 
Owen, G. E. L., 1965, “The Place of the Timaeus in Plato's Dialogues”, in: Allen 1965, pp. 313-338 (the first edition: The Classical Quarterly 47 (1953), pp. 79-95).

PARry, R. D., 1991, “The intelligible world-animal in Plato's Timaeus", Journal of the History of Philosophy 29, pp. 13-32.

Phillips, J., 2007, Order from Disorder. Proclus' Doctrine of Evil and its Roots in Ancient Platonism, Leiden - Boston.

ReYDAms-Schils, G., 1999, Demiurge and Providence. Stoic and Platonist Readings of Plato's 'Timaeus', Turnhout. Rivaud, A., 1925, Platon, Oeuvres complètes, t. X: Timée et Critias, Paris.

Serrano Cantarín, R., Díaz De Cerio Díez, M. (eds.), 2012, in : Platón. Timeo, R. Serrano Cantarin, M. Diaz De Cerio Diez, Madrid.

Skemp, J. B., 1967, The Theory of Motion in Plato's Later Dialogues, Amsterdam (the first edition: Cambridge 1942).

Skemp, J. B., 1985, “The Disorderly Motions Again”, in: Gotthelf 1985, pp. 289-299.

TARÁN, L., 1971, The Creation Myth in Plato's Timaeus, in: Anton - Kustas 1971, I, pp. 372-407.

TAYLOR, A. E., 1928, A Commentary on Plato's Timaeus, Oxford.

Trabattoni, F., 2009, Platone, Roma.

Vlastos, G., 1965, “The Disorderly Motion in the Timaeus", in: Allen 1965, pp. 379-399 (the first edition: The Classical Quarterly 33 (1939), pp. 71-83).

Voegelin, E., 1957, Order and History. Plato and Aristotle, Baton Rouge - London (repr. 1990).

Waterfield, R. (ed.), 2008, in: Plato. 'Timaeus' and 'Critias', R. Waterfield (transl.), A. Gregory (intr., notes), Oxford.

Wright, M. R. (ed.), 2000, Reason and Necessity: Essays on Plato's Timaeus, London.

ZEDDA, S., 2000, "How to build a world soul: a practical guide", in Wright 2000, pp. 23-41.

STEFANO MASO

/ Ca' Foscari University of Venice, Italy / maso@unive.it

\section{Providential Disorder in Plato's Timaeus?}

Plato tries to explain the becoming of the cosmos by referring to the concepts of order and disorder. Scholars have usually focused on the relationship between the cosmos and the demiurge that Plato puts forward to explain the reasonable (i.e., well-ordered) development. Along these lines, scholarship has examined the providential role played by both the demiurge and the soul of the world. Yet, an interesting problem still remains open: what exactly is the function of disorder? What is the sense of the concept of a perfectly established order if we do not know the manner in which it is achieved, since we have no understanding of the conditions that make it possible? Pursuing this line of thought, one may point to a providential role of the disorder given the balance of forces that operates in Plato's cosmic becoming.

Plato, disorder, order, cosmos, providence 